\title{
Edema macular cistoide bilateral por taxanos en paciente con cáncer de mama
}

\section{Bilateral cystoid macular edema due to taxanes in a patient with breast cancer}

María J Díaz-Granda y Antonio M. Garrido-Hermosilla*

UGC Oftalmología, Hospital Universitario Virgen Macarena, Sevilla; RETICS OftaRed, Instituto de Salud Carlos III, Madrid. España

Presentamos el caso de una mujer de 72 años con carcinoma mamario ductal invasivo en tratamiento quimioterápico neoadyuvante con paclitaxel que es remitida a nuestro servicio por disminución de la agudeza visual en su único ojo funcional. La retinografía revela un aumento del brillo macular, con envainamiento y disminución difusa del calibre arteriolar, así como palidez papilar bilateral (Fig. 1 A). La tomografía de coherencia

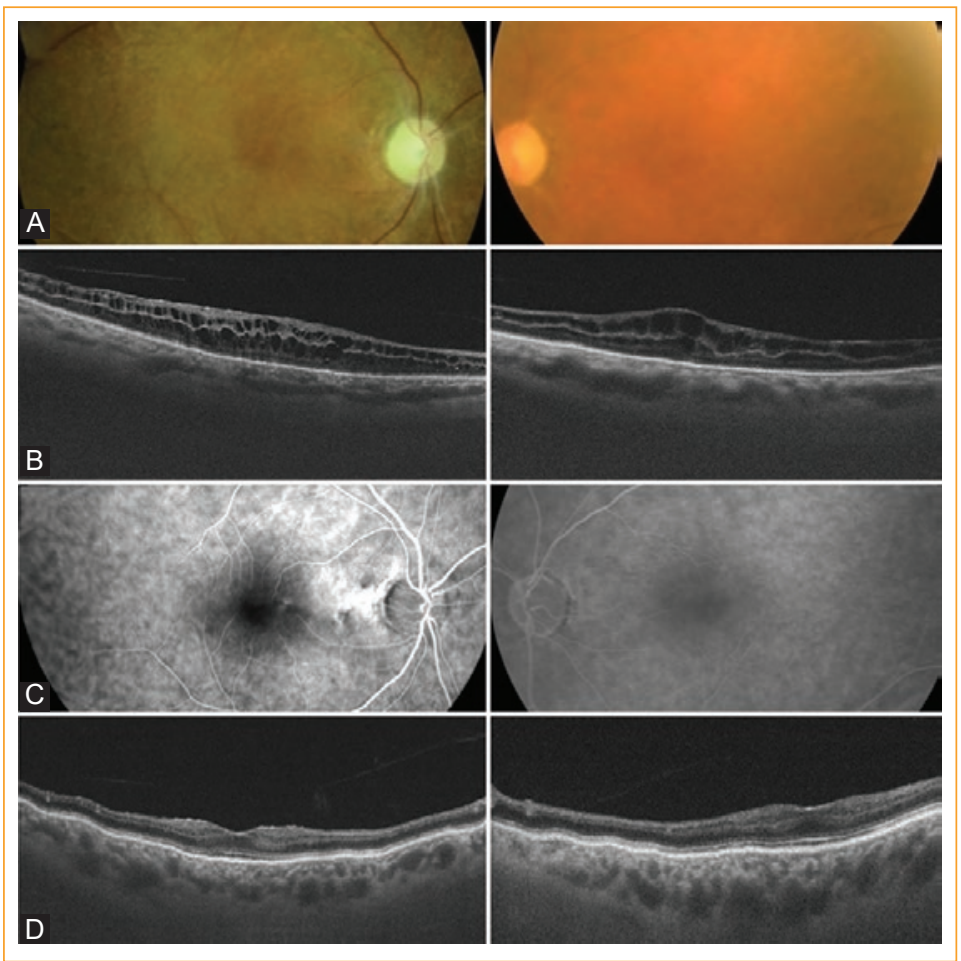

Figura 1. Imágenes multimodales retinianas del caso clínico presentado.

Correspondencia:

*Antonio M. Garrido-Hermosilla

Córdoba, 2

Fecha de recepción: 24-04-2020

C.P. 41300, San José de la Rinconada, Sevilla, España Fecha de aceptación: 22-05-2020

E-mail: gaherfamily@ hotmail.com DOI: 10.24875/RMO.M20000123
Disponible en internet: 01-09-2020 Rev Mex Oftalmol. 2020;94(5):243-244

www.rmo.com.mx 0187-4519/@ 2020 Sociedad Mexicana de Oftalmología. Publicado por Permanyer. Este es un artículo open access bajo la licencia CC BY-NC-ND (http://creativecommons.org/licenses/by-nc-nd/4.0/). 
óptica swept-source muestra esquisis retiniana y edema macular cistoide en ambos ojos (Fig. 1 B), no existiendo fuga en la angiografía fluoresceínica (fig. 1 C). Se consensúa con su oncólogo la suspensión del paclitaxel y se instaura tratamiento tópico con dorzolamida, con lo que se logra la resolución completa del cuadro de toxicidad farmacológica 8 meses después, aunque con persistencia de pliegues coriorretinianos (Fig. 1 D) ${ }^{1}$.

\section{Conflicto de intereses}

Los autores declaran no tener ningún conflicto de intereses.

\section{Responsabilidades éticas}

Protección de personas y animales. Los autores declaran que para esta investigación no se han realizado experimentos en seres humanos ni en animales.

Confidencialidad de los datos. Los autores declaran que en este artículo no aparecen datos de pacientes.

Derecho a la privacidad y consentimiento informado. Los autores han obtenido el consentimiento informado de los pacientes y/o sujetos referidos en el artículo. Este documento obra en poder del autor de correspondencia.

\section{Bibliografía}

1. Hassall MM, Andrew NH. Single-eye trial of a topical carbonic anhydrase inhibitor versus intravitreal bevacizumab for the treatment of taxane drug-induced cystoid macula oedema. BMJ Case Rep. 2016;2016:bcr2015212733. 